\title{
Response to Covid-19: An ethical imperative to build a resilient health system in India
}

\section{VIJAYAPRASAD GOPICHANDRAN, SUDARSHINI SUBRAMANIAM}

\section{Background}

China reported cases of a severe form of pneumonia in December 2019 from Wuhan city, Hubei province. The virus causing this illness was identified as the novel Coronavirus 2019, which has now been christened Covid-19. The illness is characterised by fever, cough, body pain and in a few cases, progression to acute respiratory distress syndrome (ARDS) which marks very serious damage to the lungs (1-4). Apart from Wuhan, China, the virus has spread to 26 other countries as on February 18, 2020. Of these 26 countries, the cases of Covid-19 have been exported directly from China in 23 of them. As on February 23, 2020, a total of 78,811 confirmed cases, 2445 deaths have been reported globally. The World Health Organization declared this as a Public Health Emergency of International Concern (PHEIC) on January 30, 2020 (5).

India has instituted several measures to address the Covid-19 outbreak, including airlifting of more than 600 people from Wuhan, screening them for the illness at the port of entry, quarantining them in a special facility at Manesar, Haryana, and opening an isolation ward for patients with symptoms of infection at the Indo-Tibetan Border Police Hospital in New Delhi. The National Institute of Virology in Pune has set up a research unit which is trying to sequence the genome of the virus and isolate it for further research. Thermal screening to identify people with fever has been initiated at 21 airports and several seaports. Three confirmed cases of Covid-19 have been reported in Kerala, all three of whom have been discharged from the Thrissur Medical College hospital after treatment and isolation (6). The contacts of all these confirmed cases have been traced and are under close surveillance for the onset of symptoms (7).

While China is making intensive efforts to contain the outbreak, Covid-19 specifically threatens all the weak and developing health systems of the world including the Indian health system. In situations of infectious disease outbreaks of this magnitude, there is a definite need for strong public health measures to contain it. The health system is overburdened, the human resources are burnt out and there is a scarcity of resources requiring difficult allocation decisions. Well planned public health measures can effectively contain person-to-person and source-to-person transmission.

A resilient health system is one in which the institutions, personnel, policy makers and all the important health system actors prepare for and effectively respond to crises, at the same time maintaining core system functions. There is a dire and immediate need to make the Indian public health system resilient. Health systems are complex adaptive systems and therefore improvements at multiple levels of the system can substantially add up and contribute to improved resilience (8). The government has an ethical obligation to act in the spirit of stewardship to build resilient health systems that can face such massive outbreaks and protect its people from the onslaught of emerging and re-emerging infectious diseases.

In the following paragraphs we discuss the components of resilience of the health system including the strengthening of health governance and law, establishment of disease surveillance and laboratory systems, and strengthening health human resources.

\section{Strengthening health governance and law}

While mass quarantine has been possible in China, which is an authoritarian state, it may not be as easy in more liberal democracies (9). Moreover, mass quarantines are useful only if the quarantine is leak-proof. In diseases which have high infectivity

\footnotetext{
Authors: Vijayaprasad Gopichandran (vijay.gopichandran@gmail.com - corresponding author), Assistant Professor, Department of Community Medicine, ESIC Medical College and PGIMSR, KK Nagar, Chennai 600078 INDIA; Sudarshini Subramaniam (sudharshini.subramaniam90@gmail.com), Assistant Professor, Institute of Community Medicine, Madras Medical College, Chennai 600003 INDIA.

To cite: Gopichandran V, Subramaniam S. Response to Covid-19: An ethical imperative to build a resilient health system in India. Indian J Med Ethics. 2020 Apr-Jun; 5(2)NS: 89-92.DOI:10.20529/IJME.2020.026.

Published online on March 4, 2020.

Manuscript Editor: Mala Ramanathan

Peer Reviewers: PS Rakesh and an anonymous reviewer

CIndian Journal of Medical Ethics 2020
} 
potential, even a small leak in the quarantine can lead to extensive spread of the infection. A mass quarantine of the proportions seen in China is very difficult to achieve in India. Imposing such restrictions will warrant a suspension of constitutional rights. The Epidemic Diseases Act of 1897 has legal provisions to impose restrictions in times of outbreaks. This Act has also been heavily criticised for being draconian and not relevant in the current scenario in India (10). A revised draft Public Health (Prevention, Control and Management of Epidemics, Bio-Terrorism and Disasters) Bill was tabled in 2017, but still remains to be passed. There is need for a sound legislation which is sensitive to the social determinants of health and illness, and supports containment of such outbreaks in a spirit of stewardship.

India's main response to the Covid-19 alert has been the setting up of make-shift isolation wards in the existing government medical college hospitals and re-directing of resources from other essential services to preparation of services to provide quarantine and isolation facilities. The cots, beds, IV stands, human resources and other resources that would usually be allotted to some other patients in the ward are being redirected to special isolation wards in medical college teaching hospitals. The health systems in the states are not geared for this sudden and unexpected burden. One of the major positives of the outbreak for China has been the rapid building of the new hospital in Wuhan, which China accomplished within a short span of 10 days. This infrastructure will continue to serve the population of Wuhan even after the outbreak is controlled. India may have to invest in stronger quarantine and isolation infrastructure to address such risks. The struggling public health system needs systemic strengthening before it can stand the test of an outbreak of such a magnitude.

The foremost component of a resilient health system is a committed leadership and governance framework and a financing mechanism that is responsive to crisis situations. There are two main policy formulations which are problematic from an outbreak response perspective. Firstly, the public health system is being systematically weakened in favour of the private health sector. Secondly, the emphasis is more on hospital-based curative treatments rather than public health and preventive measures. The National Health Protection Mission - Ayushman Bharat (NHPM-AB), which has been promoted as one of the largest state health insurance schemes in the world, provides for in-hospital treatment at secondary and tertiary levels of care for the poor through both the public as well as the empanelled private sector health facilities (11). This runs the risk of further weakening the public health sector in favour of the unregulated and profit driven private sector, which may not have the same level of commitment to respond to public health emergencies as the government. Infectious disease preventive strategies are within the ambit of the public health system. It is highly unlikely that the private sector will engage with preventive and public health strategies. Though there is provision for improvement of services at Health and Wellness Centres at the primary care level under the NHPM-AB, the budget allocation for this component is miniscule compared to the massive allocation for hospital-based health insurance (12). There is a need for specific budget allocation to preventive and public health activities in order for the system to be resilient during crises.

The health system must also keep a channel of transparent communication open in which it continuously updates the people about the developments in the outbreak. Such transparent communication fosters trust in the system and helps people stay prepared. While the system communicates the risk to the people, it must ensure that it avoids creating unnecessary panic (13).

\section{Establishment of robust disease surveillance and laboratory systems}

Another important function of the health system that provides resilience is a strong health information system. Information is power, and there is need for a strong surveillance system to actively know when an outbreak is happening. The International Health Regulations 2005 mandate that every member country should have a robust surveillance system. The ability of China to trace contacts and effectively put them under quarantine reflects the strength of its public health surveillance system. The robust public health surveillance system that was established by China following the SARS outbreak of 2003 has been shown to effectively document and contain many outbreaks in the country (14). The China Infectious Diseases Automated Alert and Response System (CIDARS) and the Notifiable Infectious Diseases Reporting Information System (NIDIRIS) have effectively provided early warning signals for various illnesses in the country (15). However, many countries including India, do not have robust disease surveillance systems. The lack of a disease surveillance system makes a country extremely vulnerable to attacks by infectious diseases (16).

The Integrated Disease Surveillance Project (IDSP) in India is functional, but weak (17). So far, India has detected and managed diseases which are well known such as cholera, measles, chickenpox, dengue, malaria; or those which are fatal, such as the acute encephalitis syndrome of Bihar and Uttar Pradesh or the Nipah in Kerala. We are yet to detect and respond to new infections such as Covid-19. To be ready for this, IDSP and the infectious disease surveillance system need strengthening. There is no reason to believe we are immune to outbreaks like Covid-19. It could still develop suddenly and slip through a weak surveillance machinery unless we are vigilant.

In addition to this disease surveillance system, India needs to establish a strong and coordinated laboratory infrastructure throughout the country. Apart from the National Institute of Virology in Pure, four other apex laboratories were set up towards the end of January this year to test for the virus in Alappuzha, Bengaluru, Hyderabad and Mumbai. In addition, every state has 
its own central laboratory for testing samples (18). However, this is not sufficient. More timely diagnosis and speedy reporting is possible with a strong laboratory system and surveillance by the laboratories.

\section{Strengthening health human resources}

Healthcare workers are at the vanguard of this battle against the Covid-19 virus. Their work contributes substantially to the treatment, recovery and containment of the illness. However, this also puts these frontline workers under great personal risk of contracting the illness. During the SARS-CoV outbreak of 2002 in China, healthcare workers constituted $21 \%$ of all the people who were affected (19). The death of a nurse during the recent Nipah virus outbreak in Kerala also underscored the need for the protection of healthcare workers in these outbreak situations. Healthcare workers are often over-worked and denied leave of absence during outbreaks and public health emergencies. They are separated from their families for prolonged durations. The work pressure, restriction of liberties, the fear of infection and separation from their families puts them in a situation of of severe psychological stress. The reciprocity principle demands that the state protect the interests of healthcare workers who place their lives in danger in order to care for those who are infected (20).

India faces a major health human resource crunch (21). The Nipah virus outbreak in Kerala was a great lesson on how the health system can be over-stretched during a dangerous outbreak. The hospitals and health systems were understaffed, and many contractual workers had to be employed at the last minute. The health system at the time of such outbreaks will not only require hospital workers, but also need people to carry out public health work in the community such as interviewing patients and their families, tracing contacts, implementing quarantine in communities, etc. For the Indian public health system to become resilient, it needs to invest in human resources. A strong public health cadre with good remuneration and satisfaction and pride in their work is essential. The existing staff in the public health system must undergo training in epidemiology and infection prevention. There is a need for more training in epidemiology, especially infectious disease epidemiology. The National Centre for Disease Control, under the Ministry of Health and Family Welfare, has initiated the Epidemic Intelligence Service Training Programme, which is currently a two-year training programme modelled on the US Centers for Disease Control and Prevention training programme (22). There is a need to expand this training and the service.

This is a brief exploration of the Indian health system's level of preparedness for dealing with an outbreak of the kind that we are currently seeing in China, and of the various aspects of the health system that need to be strengthened against such onslaughts. It is important to understand that China had implemented its learnings from the SARS CoV outbreak of 2003 and established several important public health mechanisms including a robust public health surveillance system (23). Further, due to China's strategic position in global trade, with multiple countries depending on it for their entire manufacturing sector, the country has more incentive to establish such a robust public health system to protect its economy. India will require greater political will that is driven by the right to health for all its people, to establish such a system. Strengthening of the health system is an ethical imperative because in a crisis, only a resilient health system can prevent deaths, resist the rapid spread of illness, be prepared to address the crisis, and simultaneously continue to provide basic essential services without coming to a standstill (8), and still be equitable and accessible to all.

\section{References}

1. Chen N, Zhou M, Dong X, Qu J, Gong F, Han Y, et al. Epidemiological and clinical characteristics of 99 cases of 2019 novel coronavirus pneumonia in Wuhan, China: a descriptive study. Lancet. 2020 Feb 15[cited 2020 Mar 1];395(10223):507-13. Epub 2020 Jan 30. Available from: https://www.thelancet. com/journals/lancet/article/PIIS0140-6736(20)30211-7/fulltext

2. Huang C, Wang Y, Li X, Ren L, Zhao J, Hu Y, et al. Clinical features of patients infected with 2019 novel coronavirus in Wuhan, China. Lancet. 2020 Feb 15 [cited 2020 Mar 1]; 395(10223):497-506. Epub 2020 Jan 24. doi: 10.1016/S0140-6736(20)30183-5

3. Wu JT, Leung K, Leung GM. Nowcasting and forecasting the potential domestic and international spread of the 2019-nCoV outbreak originating in Wuhan, China: a modelling study. Lancet. 2020 Feb 29 [cited 2020 Mar1];395(10225): 689-97.. Available from: https://www.thelancet.com/journals/ lancet/article/PIIS0140-6736(20)30260-9/fulltext

4. Lu R, Zhao X, Li J, Niu P, Yang B, Wu H, et al. Genomic characterisation and epidemiology of 2019 novel coronavirus: implications for virus origins and receptor binding. Lancet. 2020 Feb 22[cited 2020 Mar 1];395(10224): 564-75. Available from: https://www.thelancet.com/journals/lancet/article/ PIIS0140-6736(20)30251-8/fulltext

5. World Health Organization. Statement on the second meeting of the International Health Regulations (2005) Emergency Committee regarding the outbreak of novel coronavirus (2019-nCoV). Geneva:WHO; 2020 Jan 30[cited 2020 Mar 1]. Available from: https://www.who.int/news-room/detail/3001-2020-statement-on-the-second-meeting-of-the-international-health-regulations-(2005)-emergency-committee-regarding-the-outbreak-of-novelcoronavirus-(2019-ncov)

6. Press Trust of India. India's third coronavirus patient discharged from hospital in Kerala. Economictimes.indiatimes.com. 2020 Feb 21[cited 2020 Mar 1]. Available from: https://economictimes.indiatimes.com/news/politics-and-nation/indias-third-coronavirus-patient-discharged-from-hospital-in-kerala/ articleshow/74222136.cms

7. Bhargava B, Sudan P. Prepared for the coronavirus. The Hindu,com. 2020 Feb 11[cited 2020 Mar 1]. Available from: https://www.thehindu.com/opinion/ op-ed/prepared-for-the-coronavirus/article30785312.ece

8. Kruk ME, Myers M, Varpilah ST, Dahn BT. What is a resilient health system? Lessons from Ebola. Lancet. 2015 May 9[cited 2020 Mar 1];385(9980):1910-2. Available from: https://www.thelancet.com/pdfs/journals/lancet/PIIS0140-6736(15)60755-3.pdf

9. Hamblin J. A historic quarantine: China's attempt to curb a viral outbreak is a radical experiment in authoritarian medicine. Theatlantic.com. 2020 Jan 24 [cited 2020 Mar 2]. Available from: https://www.theatlantic.com/health/archive/2020/01/china-quarantine-coronavirus/605455/

10. Rakesh PS.The Epidemic Diseases Act of 1897:public health relevance in the current scenario. Indian JMed Ethics. 2016 Jul-Sep [cited 2020 Mar 2];1(3):156- 
60. Available from:https://ijme.in/articles/the-epidemic-diseases-act-of-1897-public-health-relevance-in-the-current-scenario/?galley=html

11. Lahariya C. 'Ayushman Bharat'Program and Universal Health Coverage in India. Indian Pediatr. 2018 Jun 15[cited 2020 Mar 1];55(6):495-506. Available from: https://indianpediatrics.net/june2018/june-495-506.htm

12. Gopichandran V. Ayushman Bharat National Health Protection Scheme: an Ethical Analysis. Asian Bioeth Rev. 2019 Apr 3[cited 2020 Mar 1];11(1):69-80. Available from: https://doi.org/10.1007/s41649-019-00083-5.

13. Vijaykumar S, Raamkumar AS..Zika reveals India's risk communication challenges and needs. Indian J Med Ethics. 2018 Jul-Sep[cited 2020 Mar 2]; 3(3) NS: 240-4. Epub 2018 Apr 12. Available from: https://ijme.in/articles/zika-reveals-indias-risk-communication-challenges-and-needs/

14. Li Z, Lai S, Zhang H, Wang L, Zhou D, Liu J, et al. Hand, foot and mouth disease in China: evaluating an automated system for the detection of outbreaks. Bull World Health Organ. 2014 Sep 1[cited 2020 Mar 2];92(9):656-63. Available from: https://www.who.int/bulletin/volumes/92/9/13-130666.pdf

15. Vlieg WL, Fanoy EB, van Asten L, Liu X, Yang J, Pilot E, et al. Comparing national infectious disease surveillance systems: China and the Netherlands. BMC Public Health. 2017 May 8[cited 2020 Mar 1];17(1):415. Available from: https://www.ncbi.nlm.nih.gov/pmc/articles/PMC5423001/

16. Klingler C, Silva DS, Schuermann C, Reis AA, Saxena A, Strech D. Ethical issues in public health surveillance: a systematic qualitative review. BMC Public Health. 2017 Apr 4[cited 2020 Mar 2];17(1):295. Available from: https://bmcpublichealth.biomedcentral.com/articles/10.1186/s12889-017-4200-4

17. Phalkey RK, Shukla S, Shardul S, Ashtekar N, Valsa S, Awate P, et al. Assessment of the core and support functions of the Integrated Disease Surveillance system in Maharashtra, India. BMC Public Health. 2013 Jun 13[cited 2020 Mar 2];13(1):1. Available from:https://www.ncbi.nlm.nih.gov/pmc/articles/ PMC3693947/

18. Kaul R. India ups testing mechanism as coronavirus fears grip the nation. Hindustan times.com. 2020 Jan 29 [cited 2020 Mar 2]. Available from: https:// www.hindustantimes.com/india-news/india-ups-testing-mechanism-as-virus-fears-grip-the-nation/story-41CadlgvQHLZB36OAZKpDM.html

19. World Health Organization. Summary of probable SARS cases with onset of illness from 1 November 2002 to 31 July 2003. Geneva: WHO; 2003[cited 2020 Mar 3]. Available from: http://www.who.int/csr/sars/country/table2003_09_23/en/

20. Chang D, Xu H, Rebaza A, Sharma L, Dela Cruz CS. Protecting health-care workers from subclinical coronavirus infection. Lancet Respir Med. 2020 Feb 13[cited 2020 Mar 1]; Available from: https://www.thelancet.com/pdfs/journals/lanres/PIIS2213-2600(20)30066-7.pdf

21. Nandan D, Agarwal D. Human resources for health in India: urgent need for reforms. Indian J Community Med. 2012 Oct [cited 2020 Mar 2];37(4):205-6. Available from: http://www.ijcm.org.in/article.asp?issn=0970-0218;year=2012; volume=37;issue=4;spage=205;epage=206;aulast=Nandan

22. Narain JP. India epidemic intelligence service: Advocating for a unique mentor-based epidemiology training program. Indian J Public Health. $2018 \mathrm{Jun} 14$ [cited 2020 Mar 1];62(2):143-5. Available from: http://www.ijph.in/article.asp?issn=0019-557X;year=2018; volume=62;issue=2;spage=143;epage=145;a ulast=Narain

23. Huang Y. The SARS epidemic and its aftermath in China: a political perspective. In: Knobler S, Mahmoud A, Lemon S, et al, editors. Learning from SARS: Preparing for the next Disease Outbreak: Workshop Summary. Institute of Medicine;. 2004[cited 2020 Mar 2];116-36.

\section{Integrating concerns of gender, sexuality and marital status in the medical curriculum}

\section{NIKHIL GOVIND, KETAKI CHOWKHANI}

The introduction of AETCOM (attitude, ethics and communication) (1) is seen as an effort at incorporating Medical Humanities $(\mathrm{MH})$ within the medical curriculum. For the first time, India's medical curriculum includes modules on the patient-doctor relationship, helping doctors to address ethical dilemmas that might arise during medical practice. Despite this progressive step, AETCOM has a number of drawbacks. Gayathri Prabhu (2) has analysed AETCOM as ossified, instrumental, lacking in a critical sensibility and failing to borrow from a humanities methodology. We would like to add to her excellent critique by examining other areas which have been overlooked within AETCOM. Our editorial addresses AETCOM's lack of sensibility towards the diversity of patients in India by focusing specifically on questions of gender, sexuality and marital status. While it is also important to understand how caste, religious, tribal and ethnic backgrounds of patients might be addressed within AETCOM, it is outside the scope of this editorial.

Sections within AETCOM which refer to a patient-doctor relationship do two things: one, they understand both patients and doctors as homogeneous and monolithic categories; two, they describe the different situations a patient might be in, but not the different modes of being of different patients. Patients from different socio-cultural background might have or adopt different modes of being. A failure to recognise and deal with these different modes of being of patients has led to a serious lapse in medical ethics. This has been the case with patients outside the heteronormative fold, including LGBTQ people, single people, women, adolescents and so on.

Authors: Nikhil Govind (nikhilgovind@hotmail.com), Associate Professor and Head, Manipal Centre for Humanities, Manipal Academy of Higher Education, Manipal 576 104, Karnataka, INDIA; Ketaki Chowkhani (kchowkhani@gmail.com), Postdoctoral Fellow, Manipal Centre for Humanities, Manipal Academy of Higher Education, Manipal 576 104, Karnataka, INDIA.

To cite: Govind N, Chowkhani K. Integrating concerns of gender, sexuality and marital status in the medical curriculum. Indian J Med Ethics. 2020 Apr-Jun;5(2) NS: 92-4.DOI:10.20529/JJME.2020.039.

Manuscript Editor: Olinda Timms

Peer Reviewers: Shilpa Phadke, Mala Ramanathan, Johnson Pradeep.

OIndian Journal of Medical Ethics 2020 